\title{
KEEFEKTIFAN EKSTRAK TEPUNG DAUN MIMBA (Azadirachta indica A. JUSS) DENGAN PENAMBAHAN BEBERAPA JENIS SURFAKTAN TERHADAP ULAT GRAYAK (Spodoptera litura FAB.) PADA TANAMAN KEDELAI (Glycine max L. MERRILL)
}

\author{
The Effectiveness of Neem (Azadirachta indica A. Juss ) Leaves Powder Extract with \\ Some Kind of Surfactants to Control Armyworm (Spodoptera litura Fab.) on Soybean \\ Plant (Glycine max L. Merrill)
}

\author{
Eunike JH Sidauruk, Hafiz Fauzana, Desita Salbiah \\ Mahasiswa Jurusan Agroteknologi, Fakultas Pertanian, Universitas Riau \\ Staf Pengajar Jurusan Agroteknologi, Fakultas Pertanian, Universitas Riau \\ Email: eunikesidauruk.es@gmail.com \\ [Diterima: September 2017; Disetujui: November 2017]
}

\begin{abstract}
Neem leaves powder extract is a bioinsecticide which can be used to control the pest. The active compound of neem leaves powder extract is easy to be disentangled by the ultraviolet, so that the effectiveness of application itis low in the field. The alternative to solve this problem can be used the addition surfactant to the neem leaves powder extract. The purpose of this research was to determine the influence and the kind of surfactant which is best to increase the effectiveness of neem leaves powder extract to Spodoptera litura pest on a soybean plant. The research was using a completely randomized design (CRD) with four treatments and five replications so there were 20 unit experiments. The treatment has used some kind of surfactant with the different active compound; linear alkylbenzene sulphonate (LAS), alkyl poly glycol ether (APE), alkylphenol ethoxylate (AE) and polyoxyethylene sorbitan monolaurate (PSM). The results showed the addition of synthetic surfactant with the active compound APE, AE and PSM can increase the effectiveness of neem leave powder extract $80 \mathrm{~g} / \mathrm{lof}$ water to the early death, lethal time 50 and total mortality of S. litura. The intensity attack of S. litura showed APE tends to be better to increase the effectivity of neem leaves powder extract than AE and PSM.
\end{abstract}

Keywords: Surfactant, Azadirachta indica, Spodoptera litura, and Glycine max

\begin{abstract}
ABSTRAK
Ekstrak tepung daun mimba merupakan insektisida nabati yang dapat digunakan untuk mengendalikan hama. Bahan aktif ekstrak tepung daun mimba mudah terurai oleh cahaya matahari, sehingga keefektifan dalam aplikasi di lapangan masih rendah.Alternatif untuk mengatasi masalah ini dengan penambahan surfaktan ke dalam ekstrak tepung daun mimba.penelitian ini bertujuan untuk mengetahui pengaruh dan jenis surfaktan terbaik untuk meningkatkan efektifitas ekstrak tepung daun mimba terhadap Spodoptera litura pada tanaman kedelai. Penelitian menggunakan rancangan acak lengkap (RAL) dengan empat perlakuan dan lima ulangan sehingga diperoleh 20 unit percobaan. Perlakuan yang digunakan adalah beberapa jenis surfaktan dengan bahan aktif yang berbeda; linear alkilbenzene sulfonat (LAS), alkilaril poliglikol eter (APE), alkilfenol etoksilat (AE) dan polioksietilen sorbitan monolaurat (PSM). Hasil penelitian menunjukkan penambahan surfaktan sintetis bahan aktif APE, AE dan PSM dapat meningkatkan efektifitas ekstrak tepung daun mimba 80 $\mathrm{g} /$ lair terhadap waktu awal kematian, lethal time 50 dan mortalitas total S. litura. Intensitas serangan menunjukkan bahwa APE cenderung lebih baik dalam meningkatkan efektifitas ekstrak tepung daun mimba dari pada AE dan PSM.
\end{abstract}

Kata kunci: Surfaktan, Azadirachta indica, Spodoptera litura, dan Glycine max 


\section{PENDAHULUAN}

Kedelai merupakan komoditi pangan yang banyak diminati masyarakat karena kandungan gizinya.Kedelai mengandung nutrisi yang lengkap dan dikenal sebagai sumber protein nabati yang berkualitas tinggi.Oleh karena itu, kebutuhan kedelai di Indonesia khususnya Provinsi Riau terus meningkat seiring dengan bertambahnya populasi penduduk.

Produksi kedelai di Riau mengalami penurunan.Berdasarkan data Badan Pusat Statistik Provinsi Riau (2016), produksi kedelai tahun 2012 sebesar 4.182 ton dan mengalami penurunan pada tahun 2013 menjadi 2.211 ton. Periode 2014/2015 juga terjadi penurunan produksi kedelai dari 2.332 ton menjadi 2.145 ton atau setara dengan $8,02 \%$. Gangguan hama merupakan pemicu rendahnya produktivitas kedelai. Hama utama tanaman kedelai yaitu ulat grayak Spodoptera litura.

Ulat grayak menyerang tanaman kedelai mulai dari fase vegetatif hingga generatif.Kehilangan hasil akibat serangan ulat grayak dapat mencapai $80 \%$ dan apabila serangan berat dapat menyebabkan puso (gagal panen) jika tidak dikendalikan (Marwoto dan Suharsono, 2008).

Pengendalian ulat grayak pada tanaman kedelai saat ini masih bergantung pada penggunaan insektisida kimia sintetis.Insektisida kimiasintetis mampu mengendalikan populasi hama dan meningkatkan produksi tanaman. Penggunaan insektisida kimia sintetis secara terus menerus dapat menyebabkan resistensi hama, resurgensihama dan peledakan hama sekunder (Pracaya, 2007). Alternatif mengatasi masalah yang ditimbulkan insektisida kimia sintetis dapat menggunakaninsektisida nabati.

Insektisida nabati diartikan sebagai suatu insektisida yang berbahan aktifmetabolit sekunder tumbuhan yang mampu memberikan satu atau lebih aktivitas biologi, baik pada aspek fisiologis maupun tingkah laku hama tanaman (Dadang dan Prijono, 2008). Bahan aktifinsektisida ini bersifat mudah terurai (biodegradable) dialam karena terbuat dari bahan alami sehingga tidak mencemari lingkungan, relatif aman bagi manusia dan ternak karena residunya mudah hilang (Kardinan, 2002).Tumbuhan yang berpotensi sebagai insektisida nabati yaitu mimba (Azadirachta indica).

$\begin{array}{cccr}\text { Ekstrak } & \text { daun } & \text { mimba } & \text { memiliki } \\ \text { kandungan } & \text { bahan } & \text { aktif } & \text { yaitu }\end{array}$ azadirachtin.Senyawa ekstrak ini tidak membunuh serangga dengan cepat, tetapi mempengaruhi aktivitas seperti menurunkan nafsu makan, menghambat pertumbuhan, menghambat reproduksi dan penetasan telur.Kegagalan dalam proses ini menyebabkan kematian (Samsudin, 2011). Azadirachtin bersifat toksik pada berbagai jenis hama seperti Chrysodeixis chalcites, Aphis sp., Nilaparvatalugens dan Sitophilus sp. (Dadang dan Prijono, 2008).

Mimba merupakan tanaman yang mampu menekan populasi hama karena mengandung senyawa-senyawa yang dapat mematikan serangga (Kardinan dan Dhalimi, 2003). Hasil penelitian Lestari (2014) menunjukkan bahwa ekstrak daun mimba dengan konsentrasi 80 g/l air mampu mengendalikan Maruca testulalis dengan mortalitas $90 \%$ pada tanaman kacang panjang di laboratorium.

Keefektifanekstrak daun mimba yang diuji di laboratoriumberbeda dengan pengujian di lapangan (Dadang dan Prijono, 2008). Pengujian di lapangan dipengaruhi oleh beberapa faktor antara lain cahaya matahari dan curah hujan.Cahaya matahari langsung dapat menguraikan senyawa aktif daun mimba sedangkan curah hujan dapat mencuci ekstrak daun mimba yang telah diaplikasikan pada tanaman sehingga efektifitas di lapangan rendah.

Keefektifan azadirachtin di lapangan dapat ditingkatkan melalui teknik formulasi insektisida.Formulasi insektisida merupakan gabungan dari bahan aktif, bahan pembantu (adjuvant) dan bahan pembawa (carrier). Adjuvan ditambahkan untuk meningkatkan efektifitas dari bahan aktif saat penggunaan insektisida pada tanaman..Adjuvan yang dapat digunakan sebagai campuran insektisida yaitu surfaktan. 


\section{BAHAN DAN METODE}

Penelitian telah dilaksanakan di Laboratorium Hama Tumbuhan dan Kebun Percobaan Fakultas Pertanian Universitas Riau, jalan Bina Widya km 12,5 Simpang Baru Panam, Kecamatan Tampan, Pekanbaru pada bulan Mei sampai Juli 2017. Penelitian dilaksanakan secara eksperimen menggunakan rancangan acak lengkap (RAL) dengan empat perlakuan dan lima ulangan sehingga diperoleh 20 unit percobaan. Perlakuan yang digunakan adalah beberapa jenis surfaktan dengan bahan aktif yang berbeda, yaitu:linear alkilbenzene sulfonat, alkilaril poliglikol eter, alkilfenol etoksilat dan polioksietilen sorbitan monolaurat.Parameter yang diamati adalah waktu awal kematian, lethal time 50, mortalitas harian, mortalitas total dan intensitas serangan ulat grayak.Data yang diperoleh dari penelitian dianalisis secara statistik menggunakan sidik ragam.Data yang diperoleh dari analisis ragam yaitu waktu awal kematian, lethal time 50, mortalitas total dan intensitas serangan ulat grayak dilakukan uji lanjut dengan menggunakan beda nyata jujur (BNJ) pada taraf 5\%. Data yang mortalitas harian ulat grayak dianalisis secara deskriptif dan disajikan dalam bentuk gambar.

Penelitian dilaksanakan di lapangan. Media tanam yang digunakan yaitu campuran tanah topsoil dan pupuk kandang. Penanaman kedelai dilakukan pada sore hari dan tanaman dipelihara hingga umur lima minggu setelah tanam. Tanaman diberi sungkup kayu untuk mencegah infestasi hama lain. Pemeliharaan ulat grayak dilakukan di Laboratorium Hama Tumbuhan Fakultas Pertanian Universitas Riau dengan cara telur yang diperoleh dari lapangan dibawa ke laboratorium dan dipelihara hingga menetas. Larva yang digunakan untuk infestasi adalah instar tiga.

Pembuatan ekstrak tepung daun mimba dilakukan dengan cara sebagai berikut; sebanyak $1.100 \mathrm{~g}$ daun mimba segar diambil dan dikering anginkan selama tujuh hari, setelah kering daun digunting kecilkecil lalu dihaluskan dengan blender dandiayak dengan ayakan 40 mesh. Tepung daun mimba ditimbang sebanyak $80 \mathrm{~g}$ dan dilarutkan dengan aquades $1000 \mathrm{ml}$, diaduk hingga rata dan disaring menggunakan kain kasa. Larutan ekstrak tepung daun mimba yang diperoleh dimasukkan ke dalam handsprayer $1000 \mathrm{ml}$. Langkah yang sama diulang sebanyak empat kali hingga diperoleh empathandsprayerberisi ekstrak tepung daun mimba80g/l air. Selanjutnya ditambahkan surfaktan masing-masing satu jenis surfaktan ke dalam handsprayer berisi ekstrak tepung daun mimba sebanyak $0,5 \mathrm{ml}$, diaduk hingga rata dan diberi label pada handsprayer. Aplikasi perlakuan dilakukan pada sore hari dengan volume semprot 25 ml/tanaman.Setelah aplikasi dilakukan pengamatan selama tujuh hari.

\section{HASIL DAN PEMBAHASAN Waktu Awal Kematian Ulat Grayak}

Hasil pengamatan ekstrak tepung daun mimba dengan penambahan beberapa jenis surfaktan dengan bahan aktif yang berbeda memberikan pengaruh nyata setelah dianalisis ragam terhadap waktu awal kematian ulat grayak. Waktu awal kematian ulat grayak setelah diuji lanjut beda nyata jujur (BNJ)pada taraf 5\% dapat dilihat pada Tabel 1.

Tabel 1.Waktu awal kematian ulat grayaksetelah pemberianekstrak tepung daun mimba dengan penambahan beberapa jenis surfaktan (jam)

\begin{tabular}{lc}
\hline \multicolumn{1}{c}{ Jenis surfaktan bahan aktif } & Waktu awal kematian (jam) \\
\hline Linear alkilbezene sulfonat (LAS) & $73,20 \mathrm{a}$ \\
Alkilaril poliglikol eter (APE) & $63,60 \mathrm{~b}$ \\
Alkilfenol etoksilat (AE) & $65,40 \mathrm{~b}$ \\
Polioksietilen sorbitan monolaurat (PSM) & $67,20 \mathrm{~b}$ \\
\hline
\end{tabular}

Angka-angka pada lajur yang diikuti oleh huruf kecil yang tidak sama berbeda nyata menurut uji BNJ pada taraf 5\%.

Tabel 1 menunjukkan bahwa ekstrak tepung daun mimba dengan penambahan surfaktan bahan aktif LAS menyebabkan waktu awal kematian ulat grayak yang 
berbeda nyata dengan ekstrak tepung daun mimba dengan penambahan surfaktan bahan aktif APE, AE dan PSM. Hal ini karena LAS bukan merupakan surfaktan yang dikhususkan sebagai campuran dalam formulasi insektisida sedangkan surfaktan bahan aktif APE, AE dan PSM dikhususkan sebagai surfaktan sintetis dalam formulasi insektisida.

Ekstrak tepung daun mimba dengan bahan aktif azadirachtin masuk ke dalam tubuh ulat grayak sebagai racun lambung atau racun perut dan bekerja sebagai racun penghambat pergantian kulit serangga. Azadirachtin juga bisa masuk sebagai racun kontak yaitu melalui dinding tubuh dan masuk ke dalam tubuh ulat grayak. Menurut Ardiansyah et al. (2002) mekanisme racun kontak yaitu insektisida masuk ke dalam tubuh serangga melalui kulit, dinding tubuhdan lubang alami pada tubuh.

Penambahan surfaktan ke dalam ekstrak tepung daun mimba membantu kinerja azadirachtin dengan cara memperluas sebaran semprot ekstrak tepung daun mimba pada daun kedelai. Menurut Djojosumarto (2008) bahwa surfaktan membantu membasahi bidang sasaran semprot dengan cara menurunkan tegangan permukaannya, sehingga kabut semprot menyebar secara merata ke seluruh permukaan daun. Semakin merata distribusi azadirachtin di seluruh permukaan daun kedelai, semakin besar peluang masuknya azadirachtin ke dalam tubuh ulat grayak sebagai racun lambung melalui daun kedelai yang dimakan karena daun kedelai tersebut telah mengandung senyawa azadirachtin.
Ulat grayak pada stadia larva mengalami beberapa kali pergantian kulit. Proses ini melibatkan beberapa hormon diantaranya hormon ekdison, hormon otak dan hormon juvenil (Spratt dalam Lukman, 2009). Keseimbangan ketiga hormon ini sangat dibutuhkan untuk terjadinya proses pergantian kulit pada ulat grayak. Azadirachtin yang masuk ke dalam tubuh ulat grayak akan menghambat pembentukan hormon ekdison sehingga keseimbangan hormon dalam tubuh ulat grayak terganggu dan ulat grayak tidak dapat melakukan pergantian kulit yang mengakibatkan ulat grayak tidak bisa melanjutkan siklus hidupnya.

Ekstrak tepung daun mimba dengan penambahan surfaktan bahan aktif APE, AE dan PSM menyebabkan waktu awal kematian ulat grayak berbeda tidak nyata masingmasingnya. Surfaktan bahan aktif APE, AE dan PSM memiliki fungsi yang sama yaitu sebagai perata insektisida. Menurut Novizan (2002) bahwa sifat utama surfaktan yaitu kemampuannya membasahi dan meratakan insektisida pada bidang sasaran.

\section{Lethal Time $50\left(\mathbf{L T}_{50}\right)$ Ulat Grayak}

Hasil pengamatan ekstrak tepung daun mimba dengan penambahan beberapa jenis surfaktan dengan bahan aktif yang berbeda memberikanpengaruh nyata setelah dianalisis ragam terhadap lethal time 50 ulat grayak. Lethal time 50 ulat grayak setelah diuji lanjut BNJ pada taraf 5\% dapat dilihat pada Tabel 2.

Tabel 2. Lethal time 50 ulat grayaksetelah pemberianekstrak tepung daun mimba dengan penambahan beberapa jenis surfaktan (jam)

\begin{tabular}{lc}
\hline \multicolumn{1}{c}{ Jenis surfaktan bahan aktif } & Lethal time 50 (jam) \\
\hline Linear alkilbezene sulfonat (LAS) & $124,40 \mathrm{a}$ \\
Alkilaril poliglikol eter (APE) & $109,80 \mathrm{~b}$ \\
Alkilfenol etoksilat (AE) & $110,40 \mathrm{~b}$ \\
Polioksietilen sorbitan monolaurat (PSM) & $113,40 \mathrm{~b}$ \\
\hline Angka-angka pada lajur yang diikuti oleh huruf kecil yang tidak sama berbeda nyata menurut uji BNJ pada taraf 5\%.
\end{tabular}

Tabel 2 menunjukkan bahwa pemberian ekstrak tepung daun mimba dengan penambahan surfaktan bahan aktif LAS menyebabkan lethal time 50 ulat grayak berbeda nyata dengan penambahan surfaktan sintetis bahan aktif APE, AE dan PSM. Penambahan surfaktan dengan bahan aktif LAS menyebabkan waktu awal kematian ulat grayak lebih lama yaitu 73,20 jam setelah aplikasi dibandingkan 
penambahan surfaktan sintetis bahan aktif APE, AE dan PSM yang berkisar antara 63,60-67,20 jam. Semakin cepat waktu awal kematian ulat grayak terjadi maka semakin cepat pula kematian $50 \%$ ulat grayak tercapai.

Ekstrak tepung daun mimba dengan penambahan surfaktan bahan aktif APE, AE dan PSM yang ditambahkan ke dalam ekstrak tepung daun mimba menyebabkan lethal time 50 ulat grayak berbeda tidak nyata antar perlakuan. Hal ini karena surfaktan tidak bersifat toksik bagi ulat grayak akan tetapi penambahan surfaktan membantumemperluas

azadirachtin yang disemprotkan. Penambahan surfaktan menyebabkan permukaan daun kedelai yang tertutup larutan semprot lebih luas sehingga semprotan insektisida tersebar lebih merata.

Ekstrak tepung daun mimba dengan penambahan surfaktan bahan aktif LAS menyebabkan lethal time 50 ulat grayak berbeda nyata dengan penambahan surfaktan bahan aktif APE, AE dan PSM. Hal ini juga

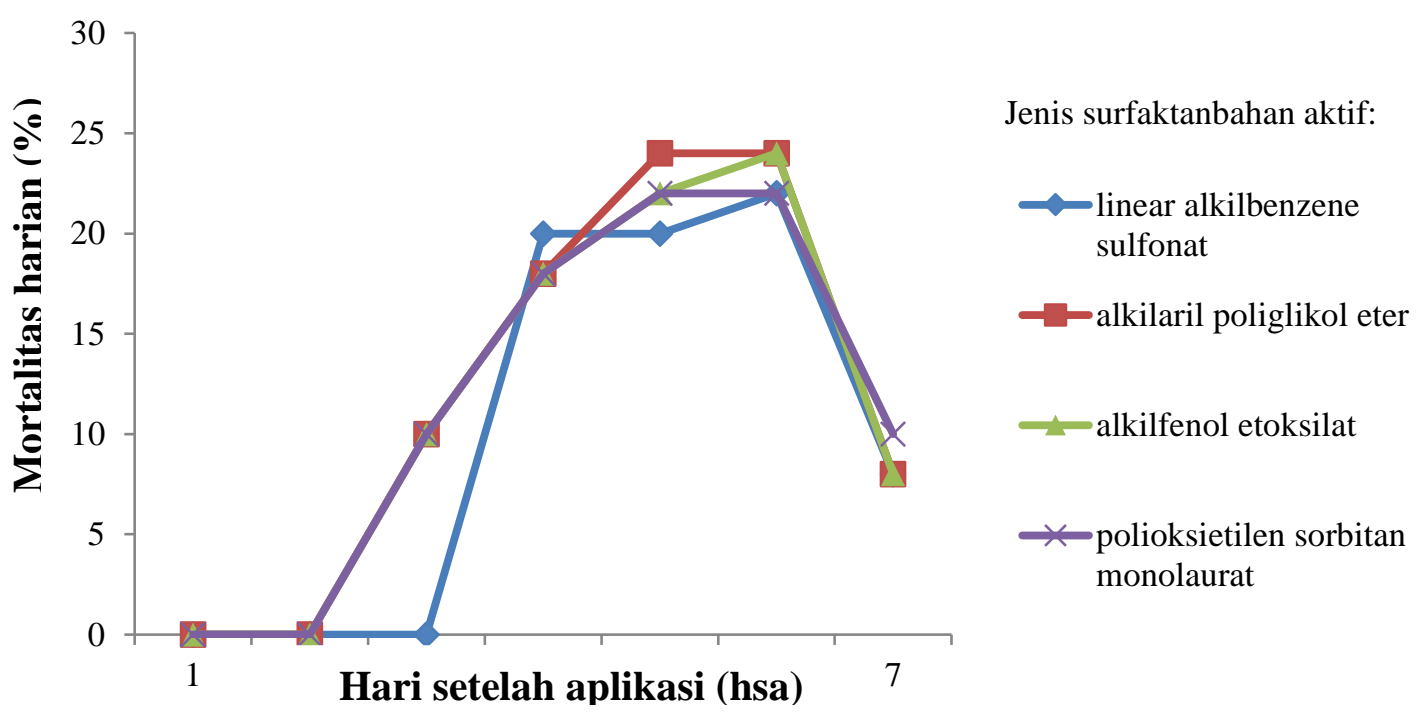

terjadi pada waktu awal kematian ulat grayak (Tabel 1). Ekstrak tepung daun mimba dengan penambahan surfaktan sintetis bahan aktif APE, AE dan PSM memberikan waktu awal kematian ulat grayak berbeda tidak nyata jika dibandingkan masing-masingnya. Ekstrak tepung daun mimba dengan penambahan surfaktan bahan aktif APE cenderung memberikan waktu awal kematian dan lethal time 50 ulat grayak tercepat dibandingkan penambahan surfaktan bahan aktif AE dan PSM.

\section{Mortalitas Harian Ulat Grayak}

Hasil pengamatan mortalitas harian ulat grayak setelah pemberian ekstrak tepung daun mimba dengan penambahan surfaktan dengan bahan aktif yang berbeda menunjukkan bahwa persentase kematian ulat grayak fluktuasi dari hari pertama hingga hari ketujuh setelah aplikasi.Fluktuasi mortalitas harian ulat grayakdapat dilihat pada Gambar 1.

Gambar 1. Fluktuasi mortalitas harian ulat grayak setelah pemberian ekstrak tepung daun mimba dengan penambahan beberapa jenis surfaktan

Gambar 1 menunjukkan bahwa mortalitas harian ulat grayak setelah pemberian ekstrak tepung daun mimba dengan penambahan beberapa jenis surfaktan mengalami fluktuasi setiap harinya. Mulai dari satu hari setelah aplikasi (hsa) belum ada ulat grayak yang mati sampai akhirnya mortalitas terus meningkat hingga mencapai puncak mortalitas pada enam hsa dan mengalami penurunan pada tujuh hsa.

Ekstrak tepung daun mimba dengan penambahan surfaktan bahan aktif LAS, AE, APE dan PSM pada satu hsa dan dua hsa 
belum mampu menyebabkan mortalitas pada ulat grayak. Menurut Indiati dan Marwoto (2008) bahwa senyawa aktif tanaman mimba tidak membunuh hama secara cepat, tapi berpengaruh terhadap daya makan, pertumbuhan, daya reproduksi, proses ganti kulit, menurunkan daya tetas telur dan menghambat pembentukan kitin.

Puncak mortalitas ulat grayak terjadi pada enam hsa. Persentase mortalitas ulat grayak tertinggi terjadi pada penambahan surfaktan bahan aktif APE dan AE masingmasing sebesar $24 \%$. Puncak mortalitas ulat grayak terjadi pada enam hsa karena azadirachtin telah bekerja maksimal di dalam tubuh ulat grayak sehingga ulat grayak lebih banyak yang mati pada enam hsa.

Pengamatan tujuh hsa menunjukkan pada masing-masing perlakuan yang diberikan terjadi penurunan persentase mortalitas harian ulat grayak. Persentase mortalitas ulat grayak untuk semua perlakuan berkisar antara $8 \%$ sampai $10 \%$. Hal ini disebabkan populasi ulat grayak yang masih hidup pada tujuh hsa sedikit karena telah banyak mengalami mortalitas pada satu hsa sampai enam hsa.

\section{Mortalitas Total Ulat Grayak}

Hasil pengamatan ekstrak tepung daun mimba dengan penambahan beberapa jenis surfaktan dengan bahan aktif yang berbeda memberikanpengaruh nyata setelah dianalisis ragam terhadap mortalitas total ulat grayak. Mortalitas total ulat grayak setelah diuji lanjut BNJ pada taraf 5\% dapat dilihat pada Tabel 3.

Tabel 3. Mortalitas total ulat grayaksetelah pemberianekstrak tepung daun mimba dengan penambahan beberapa jenis surfaktan $(\%)$

\begin{tabular}{lc}
\hline \multicolumn{1}{c}{ Jenis surfaktan bahan aktif } & Mortalitas total (\%) \\
\hline Linear alkilbezene sulfonat (LAS) & $70 \mathrm{a}$ \\
Alkilaril poliglikol eter (APE) & $84 \mathrm{~b}$ \\
Alkilfenol etoksilat (AE) & $82 \mathrm{~b}$ \\
Polioksietilen sorbitan monolaurat (PSM) & $82 \mathrm{~b}$ \\
\hline
\end{tabular}

Hasil penelitian menunjukkan bahwa pemberian ekstrak tepung daun mimba dengan penambahan surfaktan bahan aktif LAS menyebabkan mortalitas total ulat grayak berbeda nyata dengan penambahan surfaktan bahan aktif APE, AE dan PSM. Persentase mortalitas total ulat grayak yang diberikan ekstrak tepung daun mimba dengan penambahan surfaktan bahan aktif LAS lebih rendah dibandingkan dengan penambahan surfaktan bahan aktif APE, AE dan PSM. Hal ini membuktikan bahwa penambahan surfaktan bahan aktif APE, AE dan PSM telah membantu keefektifan kinerja azadirachtin dalam mematikan ulat grayak. Hasil penelitian Agustina (2017) menunjukkan penambahan surfaktan bahan aktif alkilaril poliglikol eter $0,05 \%$ ke dalam ekstrak daun sirih hutan dapat meningkatkan mortalitas ulat grayak sebesar $22,5 \%$ dibandingkan tanpa penambahan surfaktan.

Penambahan surfaktan menyebabkan azadirachtin bertahan lebih lama di permukaan tanaman kedelai sehingga kontak antara azadirachtin dengan ulat grayak lama. Menurut Djojosumarto (2008) bahwa penggunaan surfaktan membuat larutan insektisida bertahan lebih lama di permukaan daun tanaman. Dengan demikian, peluang masuknya azadirachtin ke dalam tubuh ulat grayak besar melalui makanan yang dimakan atau melalui kontak yang terjadi antara ulat grayak dengan azadirachtin.

Azadirachtin masuk ke dalam tubuh ulat grayak sebagai racun lambung maupun racun kontak dan bekerja sebagai racun penghambat pergantian kulit pada ulat grayak.Mekanisme kerja azadirachtin di dalam tubuh ulat grayak tidak dipengaruhi oleh surfaktan.

Ulat grayak yang keracunan azadirachtin menjadi tidak aktif bergerak.Ulat grayak tidak bisa melakukan pergantian kulit karena adanya senyawa azadirachtin yang menghambat ulat grayak untuk membentuk kitin, yaitu zat kimia yang 
dihasilkan serangga sebagai bahan penyusun kulitnya.Akibatnya ulat grayak tidak bisa menghasilkan kulit baru.Tubuh ulat grayak menjadi kekuningan, lemah, lama-kelamaan menghitam dan mati (Sudarmadji, 1994).

Pemberian ekstrak tepung daun mimba dengan penambahan surfaktan bahan aktif APE menyebabkan mortalitas total ulat grayak berbeda tidak nyata dengan penambahan surfaktan bahan aktif AE dan PSM. Menurut Wudianto (1997) bahwa surfaktan berfungsi sebagai bahan perata, pembasah dan perekat yang bertujuan untuk meningkatkan perataan penyebaran larutan semprot, menurunkan tegangan permukaan bidang sasaran atau memperbesar kontak antara insektisida dengan serangga uji.

Ekstrak tepung daun mimba dengan penambahan surfaktan bahan aktif APE, AE dan PSM dapat dikatakan efektif sebagai insektisida nabati karena mampu menyebabkan mortalitas ulat grayak lebih dari 80\%. Menurut Dadang dan Prijono (2008) bahwa ekstrak bahan nabati dikatakan efektif sebagai insektisida apabila dapat mengakibatkan mortalitas lebih dari $80 \%$ terhadap serangga uji.

\section{Intensitas Serangan Ulat Grayak}

Hasil pengamatan ekstrak tepung daun mimba dengan penambahan beberapa jenis surfaktan dengan bahan aktif yang berbeda memberikan pengaruh nyata setelah dianalisis ragam terhadap intensitas serangan ulat grayak. Intensitas serangan ulat grayak setelah diuji lanjut BNJ pada taraf 5\% dapat dilihat pada Tabel 4 .

Tabel 4. Intensitas seranganulat grayaksetelah pemberianekstrak tepung daunmimba dengan penambahan beberapa jenis surfaktan $(\%)$

\begin{tabular}{lc}
\hline \multicolumn{1}{c}{ Jenis surfaktan bahan aktif } & Intensitas serangan (\%) \\
\hline Linear alkilbezene sulfonat (LAS) & $57,85 \mathrm{a}$ \\
Alkilaril poliglikol eter (APE) & $41,42 \mathrm{~b}$ \\
Alkilfenol etoksilat (AE) & $44,28 \mathrm{~b}$ \\
Polioksietilen sorbitan monolaurat (PSM) & $50,71 \mathrm{ab}$ \\
\hline
\end{tabular}

Angka-angka pada lajur yang diikuti oleh huruf kecil yang tidak sama berbeda nyata menurut uji BNJ pada taraf 5\%.

Tabel 4 menunjukkan bahwa ekstrak tepung daun mimba dengan penambahan surfaktan bahan aktif LAS menyebabkan intensitas serangan ulat grayak berbeda nyata dengan pemberian ekstrak tepung daun mimba penambahan surfaktan bahan aktif APE dan AE. Pemberian ekstrak tepung daun mimba dengan penambahan surfaktan bahan aktif APE, AE dan PSM termasuk kategori serangan sedang menyebabkan intensitas serangan ulat grayak berbeda tidak nyata masing-masingnya. Ekstrak tepung daun mimba penambahan surfaktan bahan aktif PSM intensitas serangan ulat grayak berbeda tidak nyata dengan penambahan surfaktan bahan aktif APE dan AE, tetapi juga berbeda tidak nyata dengan penambahan surfaktan bahan aktif LAS. Dengan demikian, kemampuan surfaktan bahan aktif PSM lebih rendah daripada surfaktan bahan aktif APE dan AE.

Besarnya intensitas serangan berhubungan dengan proses makan ulat grayak terhadap tanaman kedelai setelah ditambahkan surfaktan ke dalam ekstrak tepung daun mimba. Proses makan ulat grayak dengan penambahan surfaktan bahan aktif APE cenderung lebih sedikit daripada penambahan surfaktan bahan aktif AE dan PSM, sehingga kerusakan daun tanaman kedelai lebih kecil.

\section{KESIMPULAN DAN SARAN}

\section{Kesimpulan}

1. Penambahan surfaktan sintetis dengan bahan aktif alkilaril poliglikol eter, alkilfenol etoksilat dan polioksietilen sorbitan monolauratke dalam ekstrak tepung daun mimba 80 glairdapat meningkatkan efektifitas ekstrak tepung daun mimba terhadap waktu awal kematian, lethal time 50, mortalitas total dan intensitas serangan ulat grayak.

2. Intensitas serangan ulat grayak memperlihatkan bahwa penambahan surfaktan dengan bahan aktif alkilaril poliglikol eter cenderung lebih baik dalam 
meningkatkan efektifitas ekstrak tepung daun mimba daripada surfaktan bahan aktif alkilfenol etoksilat dan polioksietilen sorbitan monolaurat.

\section{Saran}

Upaya pengendalian serangan ulat grayak pada tanaman kedelai sebaiknya menggunakan ekstrak tepung daun mimba 80 g/lair dengan penambahan surfaktan bahan aktif alkilaril poliglikol eter, alkilfenol etoksilat atau polioksietilen sorbitan monolaurat. Diantara ketiga surfaktan sintetis dianjurkan menggunakan bahan aktif alkilaril poliglikol eter sebagai surfaktan.

\section{DAFTAR PUSTAKA}

Agustina, E. 2017.Pengaruh penambahan surfaktan dalam ekstrak daun sirih hutan (Piper aduncum L.) untuk mengendalikan ulat grayak (Spodoptera litura F.) pada tanaman kedelai (Glycine max L. Merrill).JOM Faperta UR.4(1).

Ardiansyah, Wirianto dan Mahajoeno. 2002. Toksisitas ekstrak daun mimba (Azadirachta indica A. Juss) pada anakan siput murbei (Pomea canaliculata). BIO SMART. 4(1): 2934.

Badan Pusat Statistik Provinsi Riau. 2016. Produksi Padi, Jagung, dan Kedelai Provinsi Riau (Angka Sementara 2015). Dilihat 03 Desember 2016.<http://riau.bps.go.id>

Dadang dan D. Prijono. 2008. Insektisida Nabati: Prinsip, Pemanfaatan dan Pengembangan. Bogor: Departemen Proteksi Tanaman Fakultas Pertanian Institut Pertanian Bogor.

Djojosumarto, P. 2008. Panduan Lengkap Pestisida dan Aplikasinya.Jakarta: Agromedia Pustaka.
Indiati, S. W., dan Marwoto. 2008. Potensi ekstrak biji mimba sebagai insektisida nabati. Bulletin Palawija. (15): 9-14.

Kardinan, A. dan A. Dhalimi. 2003. Mimba (Azadirachta indica A. Juss) tanaman multi manfaat. Jurnal Perkembangan TeknologiTRO. 15(1): 1-10.

Kardinan, A. 2002.Pestisida Nabati Ramuan dan Aplikasi.Jakarta: Penebar Swadaya.

Lestari, W. 2014.Keefektifan Ekstrak Daun Mimba (Azadirachta indica A. Juss) dalam Mengendalikan Ulat Penggerek Polong (Maruca testulalis Geyer) pada Kacang Panjang di Laboratorium.Skripsi.Program Sarjana. Universitas Riau. Pekanbaru.

Lukman, A. 2009.Peran hormon dalam metamorfosis serangga.Biospesies. 2(1): 42-45.

Marwoto dan Suharsono. 2008. Strategi dan komponen teknologi pengendalian ulat grayak (Spodoptera litura Fabricus) pada tanaman kedelai. Jurnal Litbang Pertanian. 27(4): 131-136.

Novizan. 2002. Petunjuk Penggunaan Pestisida. Tangerang: Agromedia Pustaka.

Pracaya. 2007. Hama dan Penyakit Tanaman. Jakarta: Penebar Swadaya.

Samsudin. 2012. Biosintesa dan cara kerja azadirachtin sebagai bahan aktif insektisida nabati. Prosiding Semnas Pesnab IV.Balai Penelitian Tanaman Rempah dan Aneka Tanaman Industri. Jakarta.

Sudarmadji, D. 1994. Prospek dan kendala dalam pemanfaatan mimba sebagai insektisida nabati.Prosiding hasil penelitian dalam rangka pemanfaatan pestisida nabati.Pusat penelitian bioteknologi pertanian. Bogor.

Wudianto, R. 1997. Petunjuk Penggunaan Pestisida. Bogor: Penebar Swadaya. 